\title{
Phytoplankton community disruption caused by latest Cretaceous global warming
}

\author{
Johan Vellekoop ${ }^{1}$, Lineke Woelders ${ }^{1}$, Appy Sluijs ${ }^{2}$, Kenneth G. Miller ${ }^{3}$, and Robert P. Speijer ${ }^{1}$ \\ ${ }^{1}$ Department of Earth and Environmental Sciences, Division of Geology, KU Leuven, 3001 Heverlee, Belgium \\ ${ }^{2}$ Department of Earth Sciences, Marine Palynology and Paleoceanography, Laboratory of Palaeobotany and Palynology, \\ Utrecht University, 3584CB, Utrecht, the Netherlands \\ ${ }^{3}$ Department of Earth and Planetary Sciences, Rutgers University, Piscataway, New Jersey 08854, USA
}

Correspondence: Johan Vellekoop (johan.vellekoop@kuleuven.be)

Received: 11 June 2019 - Discussion started: 30 July 2019

Revised: 1 October 2019 - Accepted: 7 October 2019 - Published: 7 November 2019

\begin{abstract}
Phytoplankton responses to a $~ 350 \mathrm{kyr}$ (kiloyear) long phase of gradual late Maastrichtian (latest Cretaceous) global warming starting at $\sim 66.4 \mathrm{Ma}$ can provide valuable insights into the long-term influences of global change on marine ecosystems. Here we perform micropaleontological analyses on three cores from the New Jersey paleoshelf to assess the response of phytoplankton using cyst-forming dinoflagellates and benthic ecosystems using benthic foraminifera. Our records show that this latest Maastrichtian warming event (LMWE), characterized by a $4.0 \pm 1.3^{\circ} \mathrm{C}$ warming of sea surface waters on the New Jersey paleoshelf, resulted in a succession of nearly monospecific dinoflagellate-cyst assemblages, dominated by the species Palynodinium grallator. This response, likely triggered by the combination of warmer and seasonally thermally stratified seas, appears to have been more intense at offshore sites than at nearshore sites. The LMWE, and related dinoflagellate response, is associated with an impoverished benthic ecosystem. A wider geographic survey of literature data reveals that the dominance of $P$. grallator is a marker for the LMWE throughout the northern midlatitudes. While the dinocyst assemblage returned to a stable, normal marine community in the last tens of thousands of years of the Maastrichtian, benthic foraminiferal diversity appears to have remained slightly suppressed. Increased ecosystem stress during the latest Maastrichtian potentially primed global ecosystems for the subsequent mass extinction following the Cretaceous Paleogene $(\mathrm{K}-\mathrm{Pg})$ boundary Chicxulub impact.
\end{abstract}

\section{Introduction}

Anthropogenically forced increases in atmospheric greenhouse gas concentrations are projected to substantially impact climate on a global scale in the near future (IPCC; Pachauri et al., 2014). In the oceans, increasing concentrations of greenhouse gases are expected to increase surface temperatures, lower $\mathrm{pH}$, and cause changes to vertical mixing and upwelling (Pachauri et al., 2014). The higher upper ocean temperatures predicted under future climate scenarios will increase stratification of the water column and differentially affect growth of phytoplankton groups in the global oceans (Behrenfeld et al., 2006; Boyd and Doney, 2002; Doney, 2006). Such a warmer ocean might bear analogies in the Cretaceous to Paleogene greenhouse world (Hay, 2011). The geological record indicates that this greenhouse world favored dinoflagellates and coccolithophorids among the eukaryotic phytoplankton (Falkowski et al., 2004). Importantly, dinoflagellates are a key group of phytoplankton responsible for marine harmful algal blooms (Hallegraeff, 1993). It is likely that the frequency, duration and intensity of marine dinoflagellate blooms will increase as a result of a warming climate (Hallegraeff, 1993; Moore et al., 2008), which is supported by some paleoceanographic studies (Cramwinckel et al., 2019). Yet, the potential consequences of such largescale patterns of climate variability for marine dinoflagellate communities are not well understood (Moore et al., 2008).

The latest Maastrichtian (i.e., latest Cretaceous) warming event (LMWE; 66.4-66.1) has been linked to severe disturbance of marine ecosystems (Petersen et al., 2016; Schoene et al., 2015; Woelders et al., 2017). This LMWE, likely re- 
lated to an exceptionally large volcanic outpouring phase of the Deccan Traps large igneous province (Ravizza and Peucker-Ehrenbrink, 2003), represents a $3-7^{\circ} \mathrm{C}$ warming of sea surface temperatures (SST) in the last $\sim 350 \mathrm{kyr}$ of the Cretaceous (Olsson et al., 2002; Petersen et al., 2016; Vellekoop et al., 2016; Woelders et al., 2018). While the end-Cretaceous mass extinction event has been confidently linked to the Chicxulub impact (Schulte et al., 2010), it has been suggested that the LMWE increased ecosystem stress during the latest Maastrichtian, potentially priming global ecosystems for the subsequent mass extinction (Petersen et al., 2016). In recent work (Vellekoop et al., 2016; Woelders et al., 2018), we recorded the LMWE in three cores on the New Jersey paleoshelf (USA) using paleotemperature proxies, including TEX T6 $_{8}$ (Schouten et al., 2002). The SST records of Meirs Farm, Fort Monmouth 3 and Bass River (Fig. 1) portray fairly stable Maastrichtian SSTs followed by a sharp rise by $4.0 \pm 1.3{ }^{\circ} \mathrm{C}$ in the last $\sim 0.4$ million years of the Cretaceous (Vellekoop et al., 2016; Woelders et al., 2018; Fig. S1 in the Supplement). Importantly, Meirs Farm and Fort Monmouth 3 are inner shelf sites (Miller et al., 2010; Vellekoop et al., 2016), while Bass River (ODP 174AX) is a middle to outer shelf locality (Esmeray-Senlet et al., 2015). Together, they provide an inshore-to-offshore transect (Fig. 1; Text S1 - Materials and Methods in the Supplement). Here, we perform palynological analyses to assess the dinoflagellate response to this warming event along this shelf transect. Furthermore, to understand the process of benthic-pelagic ecosystem coupling in this setting, we complement our palynological analyses with benthic foraminiferal analyses of the uppermost Maastrichtian of Bass River.

\section{Materials and methods}

For palynological analyses, 90 oven-dried samples $(\sim 5-$ $10 \mathrm{~g}$ dry mass) of the Meirs Farm, Fort Monmouth 3 and Bass River cores were processed at Utrecht University. A known amount of Lycopodium clavatum spores were added to the samples from Bass River and Meirs Farm for quantification purposes. Chemical processing comprised treatment with $10 \% \mathrm{HCl}$ and $40 \% \mathrm{HF}$ for carbonate and silica removal, respectively. Ultrasonication was used to disintegrate palynodebris. Residues were sieved over a $15 \mu \mathrm{m}$ mesh and mounted on microscope slides, which were analyzed at $\times 200$ and $\times 1000$ magnification to a minimum of 250 dinocysts (Table S3 in the Supplement). For the taxonomy used, see Text S1). All slides are stored in the collection the Department of Earth and Environmental Sciences, KU Leuven, Belgium.

Previous work has indicated that late Cretaceous and $\mathrm{Pa}$ leogene dinoflagellate paleoecology is best assessed by assessing the stratigraphic and spatial distribution of morphologically related genera (e.g., Brinkhuis, 1994; Frieling and Sluijs, 2018; Sluijs et al., 2005). Following Schiøler et al. (1997), Machalski et al. (2016), and Sluijs and Brinkhuis (2009), we assigned the recorded dinocyst taxa to eight different morphological groups to extract paleoenvironmental signals: (1) the Spiniferites group, combining all species of Spiniferites and the morphologically related genus Achomosphaera; (2) the Areoligera group, lumping all dorsoventrally compressed gonyaulacoid cysts with an apical archeopyle, such as Glaphyrocysta and Areoligera; (3) the Hystrichosphaeridium group, combining all species within the genus Hystrichosphaeridium; (4) peridinioids, combining all peridinioid dinocysts, apart from Manumiella seelandica; (5) fibrous cribroperidinioids, combining all Cribroperidinioidea with a fibrous wall, such as Cordosphaeridium, Disphaerogena, Damassadinium and Fibrocysta; (6) Palynodinium grallator; (7) Manumiella seelandica, and (8) other dinocysts, combining all dinocysts that are not assigned to any of the previous groups.

For benthic foraminiferal analysis, 31 samples of the Bass River core were weighed and washed over a mesh of $63 \mu \mathrm{m}$ at KU Leuven. A suitable split with approximately 200400 specimens was obtained from the fraction greater than $125 \mu \mathrm{m}$ with a microsplitter. From this split all the specimens were picked, counted and mounted on micropaleontological slides (Table S2). For the taxonomy used, see Text S1.

\section{Results}

\subsection{Dinocysts}

Our dinoflagellate-cyst records show a strong response to the LMWE (Tables S1-S5; Figs. 2 and S2-S4; full dataset available at PANGAEA, Vellekoop et al., 2019). The interval before the LMWE is characterized by stable, normal marine dinocyst assemblages, typically dominated by the Spiniferites and Areoligera groups and peridinioids, with comparatively high diversity, indicated by average Shannon $H$ values of 3.0. At the onset of the warming, there is a transition to assemblages that are alternatingly dominated by one or two specific dinocyst taxa (Fig. 2), with Shannon $H$ diversity dropping to $<0.75$ (Fig. 3). The dominant taxa are $\mathrm{Pa}$ lynodinium grallator and fibrous cribroperidinioids, with the latter mostly represented by Disphaerogena carposphaeropsis. At these peak abundances, in particular $P$. grallator generally represent $>50 \%$ of the assemblages, reaching $>80 \%$ in many samples, where it occur as near-monospecific aggregates of dinocysts (Fig. S5).

With respective first appearance dates of 66.77 and 67.0 Ma (e.g., Williams et al., 2004), both $P$. grallator and $D$. carposphaeropsis were already well-established before the LMWE but generally occurred in low numbers (usually well below $5 \%$ of the total dinocyst assemblage). At the onset of the LMWE, relative abundances of these taxa increased considerably. Within the LMWE interval, concentrations of dinocysts (in cysts per gram) increase - a doubling at Meirs 
(a)

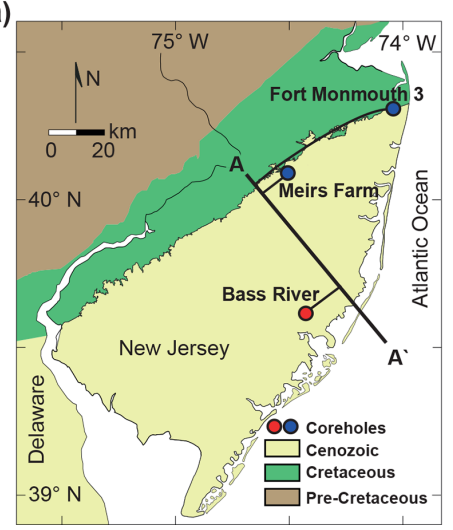

(b)

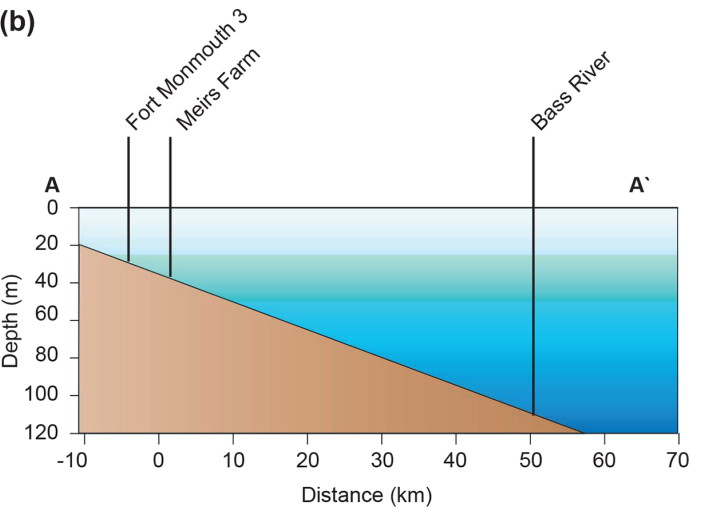

Figure 1. Geological map and paleoslope model of the New Jersey coastal plain. (a) Geological map of the New Jersey coastal plain. Bass River (Miller et al., 1998) is indicated by the red circle, and the cores drilled by the Rutgers University K-Pg boundary drilling project (Miller et al., 2010) are indicated by blue circles. (b) Paleoslope model of the New Jersey shelf showing locations of Bass River, Meirs Farm and Fort Monmouth 3, following Esmeray-Senlet et al. (2015), assuming a paleoslope of $1: 750$. Vertical exaggeration: $250 \times$.

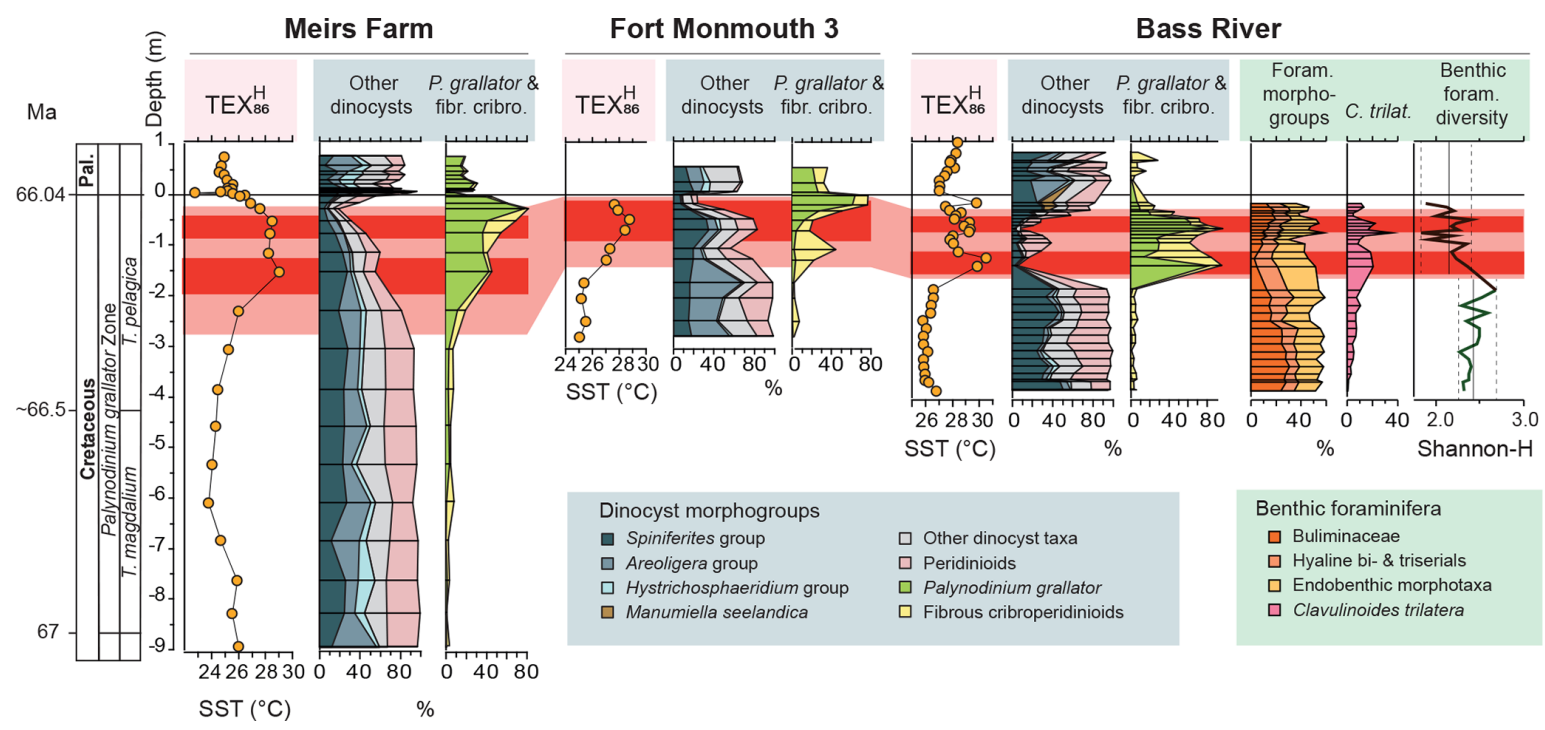

Figure 2. Relative abundances of dinocyst and benthic foraminiferal morphological groups and TEX 86 SST records of Bass River, Meirs Farm and Fort Monmouth 3. TEX 86 data of Meirs Farm and Fort Monmouth 3 are from Vellekoop et al. (2016); TEX 86 data of Bass River are from Woelders et al. (2018). Depth in meters distance from the K-Pg boundary. The latest Maastrichtian warming interval is indicated in pink and red, with red marking peak warmth. For the stratigraphy and age models, see Text S2 - Age Model; for the raw data, see Tables S1S6. Foraminiferal morphogroups are cumulative. In these foraminiferal morphogroups, Clavulinoides trilatera is included in the endobenthic morphotypes. The total variation and average benthic foraminiferal diversity values are indicated for the prewarming and warming intervals. Pal. - Paleogene; T. pelagica - Thalassiphora pelagica; T. magdalium - Tanyosphaeridium magdalium; C. trilat. - Clavulinoides trilatera.

Farm and a 10-fold increase at Bass River (Tables S4 and S5). This increase is entirely caused by the additional contribution of $P$. grallator and fibrous cribroperidinioid cysts, as the concentrations of other dinocysts taxa (in cysts per gram) remained rather stable (Fig. 4), ruling out a condensed section as the mechanism causing the observed high concentrations of dinocysts. While sea-level changes could potentially have significantly affected water depth and therefore sedimentation rates and microenvironments, an increase in only one taxon, with other taxa remaining rather stable, is diffi- cult to reconcile with such changes in sedimentation rates. Moreover, previous studies have argued for relatively constant sedimentation rates and sea level during the latest Maastrichtian of the New Jersey coastal plain (Olsson et al., 2002; Vellekoop et al., 2016; Woelders et al., 2018). Hence, the peak abundances of these taxa likely reflect massive production and deposition rates of dinoflagellate cysts. Whether this reflects an increase in encystment behavior or greater abundances of the vegetative cells remains difficult to assess in deep time records. 


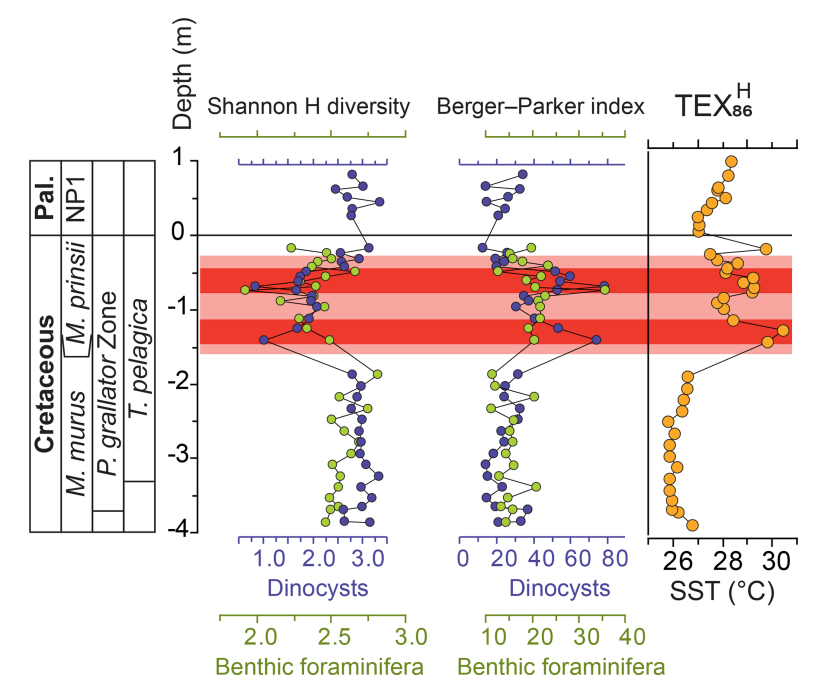

Figure 3. Overview of benthic foraminiferal and dinocyst diversity indices. TEX 86 SST record of ODP 174AX Bass River (Woelders et al., 2018) and Shannon $H$ diversity and Berger-Parker index of the benthic foraminifera (green) and dinocysts (blue) of the Bass River core. For the raw data, see Tables S1 and S6. Pal. - Paleogene; T. pelagica-Thalassiphora pelagica; M. - Micula.

Peak abundances of $P$. grallator have also been recorded at various other latest Maastrichtian localities in northern midlatitudes, such as Poland and the North Sea basin (Machalski et al., 2016; Schiøler and Wilson, 1993). Mapping our and previously published data (Fig. 5) shows that these massive cyst production events were a widespread phenomenon during the LMWE, occurring throughout large parts of the Northern Atlantic and Northern Europe. Accordingly, assemblages characterized by a dominance of $P$. grallator appear to be a marker for this event throughout the northern midlatitudes. Similarly, among other phytoplankton groups, e.g., calcareous nannoplankton, the LMWE is also marked by peak occurrences of specific taxa, such as Micula murus in low latitudes and Watznaueria barnesiae at midlatitudes (Sheldon et al., 2010; Thibault and Gardin, 2006; Thibault and Husson, 2016). The LMWE thus caused strong phytoplankton community perturbations worldwide.

\subsection{Benthic foraminifera}

Our benthic foraminiferal record of Bass River shows that the LMWE, and related perturbation of the dinoflagellate assemblages, also affected the benthic ecosystem of the New Jersey paleoshelf (Figs. 2, 3 and S6; full dataset available at PANGAEA, Vellekoop et al., 2019). Benthic foraminiferal diversity was highest before the LMWE, when the stable dinocyst assemblage is characterized by normal marine taxa. During the LMWE, benthic foraminiferal diversity drops (Shannon $H$ from 2.5 to $<2.0$; Figs. 3 and S7, Table S6). Moreover, the onset of the LMWE is characterized by a decrease in the relative abundance of bi- and triserial endobenthic morpho- types (Fig. 2), a group that is generally considered typical for high-nutrient, low-oxygen conditions (Jorissen et al., 2007). Similarly, Olsson et al. (2002) also reported a distinct benthic foraminiferal biofacies restricted to the LMWE at the New Jersey paleoshelf.

\section{Discussion}

\subsection{Causes of the $\boldsymbol{P}$. grallator dominance}

Peak abundances of $P$. grallator occurring during warming intervals around the $\mathrm{K}-\mathrm{Pg}$ boundary interval raise the question to which environmental changes these dinoflagellates respond. Modeling responses of marine species and communities to modern climate change have shown that changes in local thermal regimes, caused by climate change, can cause nonlinear changes in the global ocean, including abrupt community shifts (Beaugrand et al., 2019). It is therefore likely that the LMWE caused similar large-scale community shifts amongst global marine phytoplankton communities. Traditionally, abundances of $P$. grallator were interpreted to reflect a cooling signal in relatively low latitude Tethyan records such as El Kef and Elles in Tunisia (Brinkhuis et al., 1998; Vellekoop et al., 2015). This is because abundances of this species in Cretaceous sedimentary sequences are generally restricted to boreal regions (Brinkhuis et al., 1998). However, the massive increase in relative abundance of $P$. grallator during the LMWE (Fig. 6) implies that its thermal tolerances were not the limiting factor in its distribution before the LMWE. In turn, this indicates that an environmental factor other than temperature change allowed for it to flourish. Several studies have suggested that the LMWE caused intensification of the hydrological cycle and increased freshwater input at shelf localities (Woelders et al., 2017). Yet, there is no apparent increase of inferred freshwatertolerant dinoflagellate-cyst taxa (Frieling and Sluijs, 2018) at the New Jersey paleoshelf (Fig. 2). Moreover, dorsoventrally compressed gonyaulacoid cysts like $P$. grallator are typically not considered indicative of high-nutrient, lowsalinity conditions (Frieling and Sluijs, 2018). The absence of a clear runoff or salinity signal in both the dinocyst and foraminiferal records, i.e., no peak in either the Senegalinium complex or in bi- and triserial endobenthic morphotypes, respectively, seems to rule out runoff or freshwater input as a trigger for the massive abundances of $P$. grallator. Similarly, while patterns like a sea-level fall could also result in environmental perturbations, affecting the dinoflagellate community at these shallow shelf sites (Sluijs et al., 2005; Vellekoop et al., 2017), no sedimentological or paleontological evidence exists for any major changes in sea level across this interval at the New Jersey shelf (Miller et al., 1998; Woelders et al., 2018).

Based on a quantification of relations between dinoflagellate assemblages and high-quality geochemical and sed- 


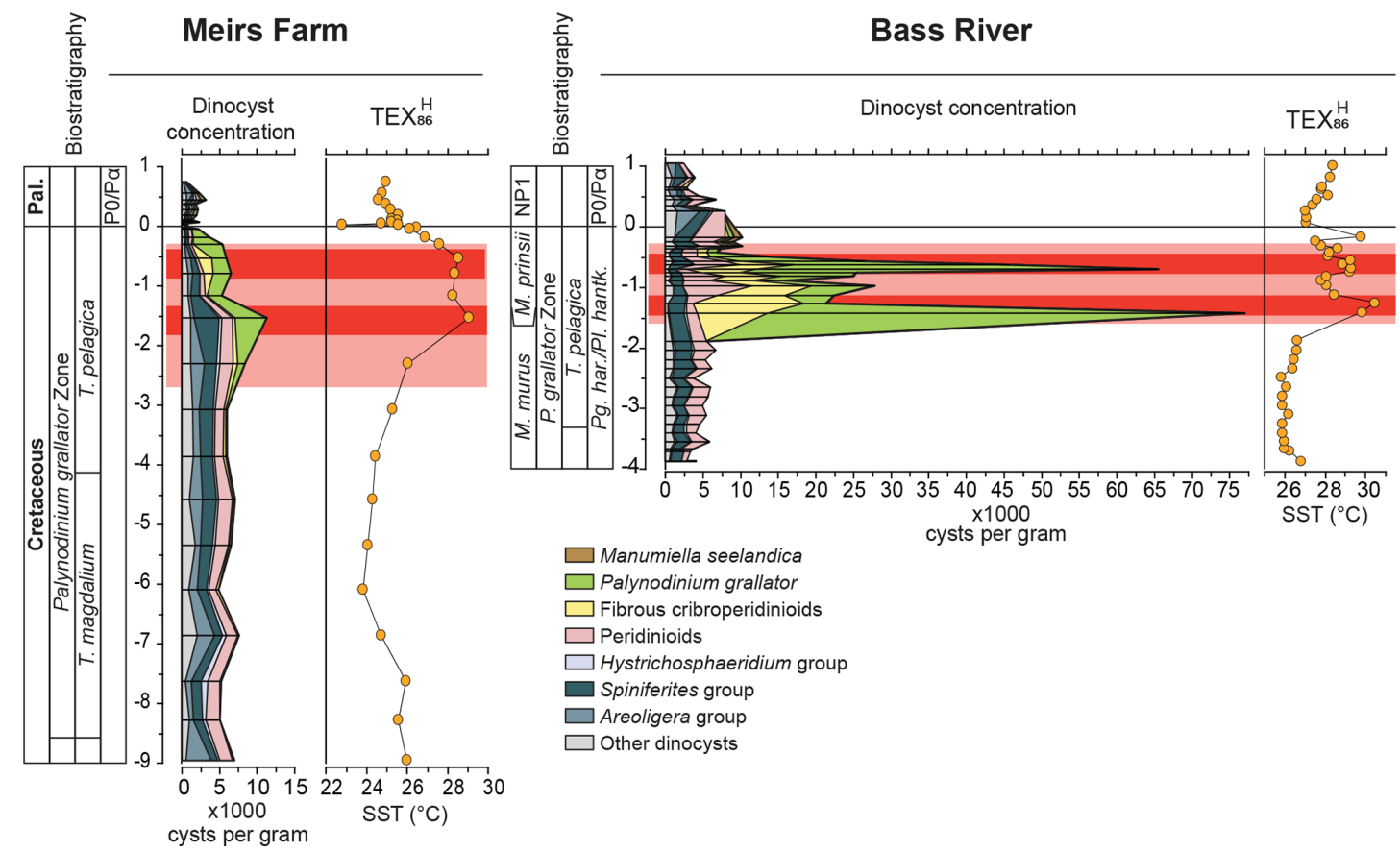

Figure 4. TEX $_{86}$ SST records and concentrations of dinocysts for Meirs Farm and Bass River. Dinocyst concentrations in cysts per gram of dry sediment. For the raw data, see Tables S4 and S5. M. - Micula; Pg. har. - Pseudoguembelina hariiaensis; Pl. hantk. - Plummerita hantkeninoides. For other abbreviations, see Fig. 2.

imentological data from sedimentary archives, Frieling et al. (2018) argued that high abundances of dorsoventrally compressed gonyaulacoid cysts could reflect recurring strong stratification. Possibly, the $4.0 \pm 1.3^{\circ} \mathrm{C}$ warming of surface waters resulted in a more frequent thermally stratified waters over the New Jersey paleoshelf. We argue that the combination of a more frequent thermally stratified water column with higher mean annual seawater temperatures during the LMWE stimulated dinoflagellate-cyst production. Conceivably, although we cannot assess annual production rates with our data, the recorded enhanced dinoflagellatecyst production could be the result of recurrent dinoflagellate blooms. Dinoflagellates generally outcompete other phytoplankton groups in a more thermally stratified water column because of their mobility (Moore et al., 2008). In addition, if the already relatively high sea water temperatures in the late Cretaceous were somehow still limiting productivity, increased temperatures during the LMWE may have further boosted growth rates (Eppley, 1972) and resulted in longerlasting annual bloom windows (Hallegraeff, 2010). Moreover, bloom-forming dinoflagellates often flourish in stressful environmental conditions that are harmful to other phytoplankton (Almeda et al., 2018), giving them an advantage over other eukaryotic phytoplankton groups. Studies on modern bloom-forming dinoflagellate taxa have shown that their toxic or unpalatable nature disrupts top-down grazer control, thereby facilitating the formation of massive, monospecific blooms (Waggett et al., 2012). The occurrence of dinoflag- ellate blooms can therefore lead to a positive feedback loop that supports bloom formation while simultaneously starving the grazing species of the ecosystem (Waggett et al., 2012), providing a mechanism for the proliferation of blooming dinoflagellate taxa.

The massive abundance of $P$. grallator in our records likely reflects the response of an opportunistic species to environmental stress in sea surface waters, potentially caused by the conjunction of warming causing stratification with other forms of environmental changes during the LMWE, for example ocean acidification caused by Deccan volcanism (Henehan et al., 2016). The strong increase in total dinocyst accumulation during the LMWE suggests that dinoflagellate productivity increased as a result of these environmental changes. A remarkable feature of the dinoflagellate response recorded on the New Jersey paleoshelf is the persistence of the amplified dinoflagellate-cyst production, maintained throughout the LMWE (i.e., more than $250 \mathrm{kyr}$ ). While we cannot positively confirm that the recorded amplified dinoflagellate-cyst production is linked to actual dinoflagellate blooms, we hypothesize that throughout the LMWE the conditions were repeatedly favorable for dinoflagellate blooms. Repeated favorable conditions would have resulted in the recurrence of such blooms throughout the event. If true, our records would not reflect one long-lasting dinoflagellate bloom but rather the sum of many blooms. As the number of cysts produced during each bloom will likely have been a multitude of the normal annual production, a strong 


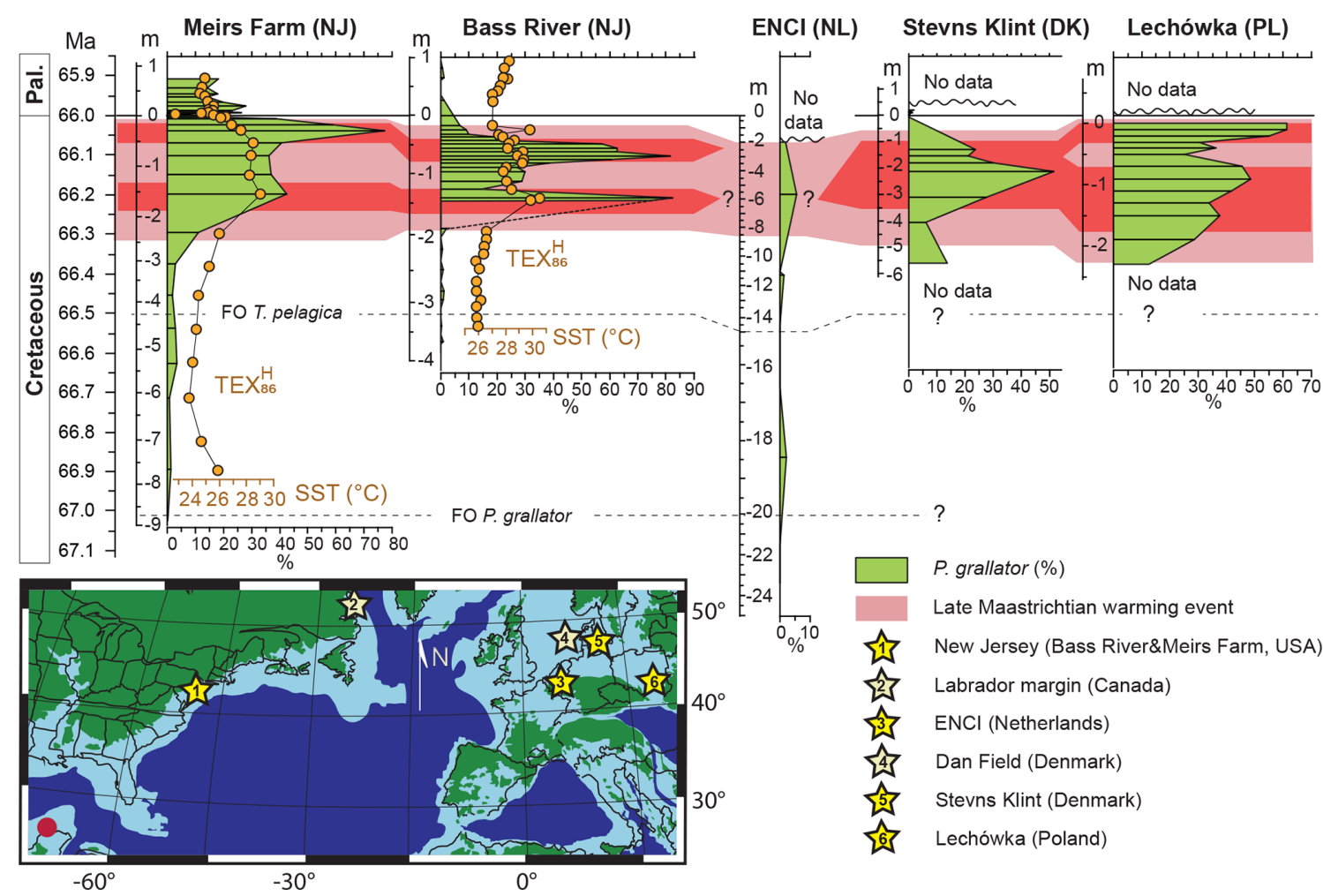

Figure 5. Palynodinium grallator acme across the boreal bioprovince. Relative abundances of $P$. grallator through the last million years of the Cretaceous on the New Jersey Paleoshelf (this study), the Maastrichtian type area (Schiøler et al., 1997); Stevns Klint (Denmark; Vellekoop et al., 2018) and Lechówka (Machalski et al., 2016). For ENCI, Stevns Klint and Lechówka, the peak warmth is inferred based on the $P$. grallator abundances. The red dot marks the Chicxulub impact site. Peak abundances of $P$. grallator in the topmost Maastrichtian are also recorded in the qualitative records of the Labrador margin (Canada; Nøhr-Hansen et al., 2016) and the North Sea Dan field (Schiøler and Wilson, 1993).

bloom every few years could have resulted in a palynological record dominated by blooming taxa throughout the LMWE. Perhaps this can explain why, even though $P$. grallator is very abundant throughout the event, "normal marine" taxa like Spiniferites consistently occur in almost the same concentrations in cysts per gram as before the event. These cysts could reflect the "normal" years in between the recurrent $P$. grallator blooms.

Our records show that the enhanced dinoflagellate-cyst production was not uniform for the entire New Jersey paleoshelf. In the shallower, more proximal sites of Fort Monmouth 3 and Meirs Farm, the cyst-producing dinoflagellate community was less affected than at the outer shelf Bass River site (Figs. 2 and 4). In modern coastal systems, tideand wind-driven mechanisms dominate algal bloom formation in shallow well-mixed systems, while density-driven exchange controls algal bloom formation in deeper, seasonally stratified systems (Pitcher et al., 2010). The difference in intensity recorded in our records is likely related to such local paleoceanographic differences.

\subsection{Benthic-pelagic ecosystem coupling}

In modern-day shallow marine settings, algal blooms are often associated with bottom water deoxygenation, related to short-term massive input of organic matter (Moore et al., 2008). Yet, the foraminiferal assemblages from the more open marine Bass River site rather suggests an overall decrease in food supply to the sea floor during the LMWE, without any indication for deoxygenation (i.e., no proliferation of bi- and triserials). Benthic foraminiferal abundances (in foraminifera per gram), which can be used as a proxy for food abundance on the sea floor (Jorissen et al., 2007), do not increase during the enhanced dinoflagellate-cyst production event in our record (Fig. S7), which also indicates that the food flux to the sea floor did not increase during the LMWE. This means that, paradoxically, while our dinocyst record suggests increased productivity, the produced organic matter did not reach the sea floor. Alternatively, the quality of the supplied organic matter was less during the LMWE. We postulate that, at the relatively offshore Bass River site, the combination of such thermally driven oceanographic changes and the recurring massive dinocyst production had a profound effect on both the mode as well as the type and amount of food 


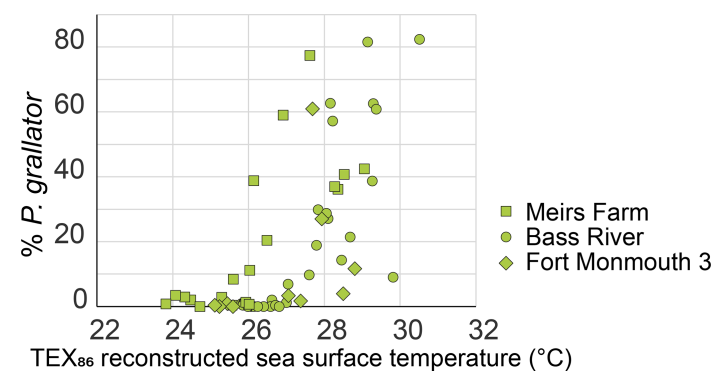

Figure 6. Relative abundances of Palynodinium grallator versus temperature. $\mathrm{TEX}_{86}$ sea surface temperatures of ODP 174AX Bass River (Woelders et al., 2018) and Meirs Farm and Fort Monmouth 3 (Vellekoop et al., 2016) versus relative abundances of Palynodinium grallator (this study), for the uppermost Maastrichtian. Paleocene samples are not included in this cross plot.

supply to the sea floor. Warmer and more stratified sea waters likely resulted in higher respiration rates of sinking organic matter. In addition, under some more thermally stratified settings, the total phytoplankton biomass decreases, as nutrients become limiting in the photic zone (Behrenfeld et al., 2006; Doney, 2006), likely also resulting in a decreasing food supply to the sea floor (Waggett et al., 2012). Likewise, during the Middle Eocene Climatic Optimum, a similar warming event which took place ca. $40 \mathrm{Ma}$ (Bohaty and Zachos, 2003), dinoflagellate blooms also coincided with a collapse of export productivity, resulting from intensified thermal stratification (Cramwinckel et al., 2019).

The benthic foraminiferal community at Bass River may have been affected by changing surface ocean conditions across the New Jersey paleoshelf, including increased dinoflagellate-cyst production. The benthic foraminiferal record of Bass River shows an increase of the relative abundance of the calcareous agglutinated foraminiferal taxon Clavulinoides trilatera, which increases from $<10 \%$ of the assemblage before the warming interval to $20 \%-35 \%$ of the assemblage during the dinoflagellate-cyst peaks (Fig. 2). Our record suggests that $C$. trilatera may have profited from massive deposition of dinoflagellate cysts, as shown by the significant positive correlation between the relative abundances of $C$. trilatera and P. grallator $\left(R^{2}=0.55 ; p\right.$ value $<0.01$; Fig. 7). We speculate that this taxon might have been feeding on dinocysts or detritus derived from the hypothesized dinoflagellate blooms, potentially similar to modern-day "bloom-feeding" foraminifera (Kitazato et al., 2000; Lee, 1966). In the period after the LMWE, during the last tens of thousands of years of the Maastrichtian, the preLMWE dinocyst assemblages returned, indicating more normal marine conditions, while benthic foraminiferal diversity at Bass River does not show a full recovery in the latest Maastrichtian (Fig. 3). The two samples above the LMWE interval are still characterized by a lower benthic foraminiferal diversity, compared to the prewarming interval, while dinocyst diversity does return to pre-LMWE values (Fig. 3).

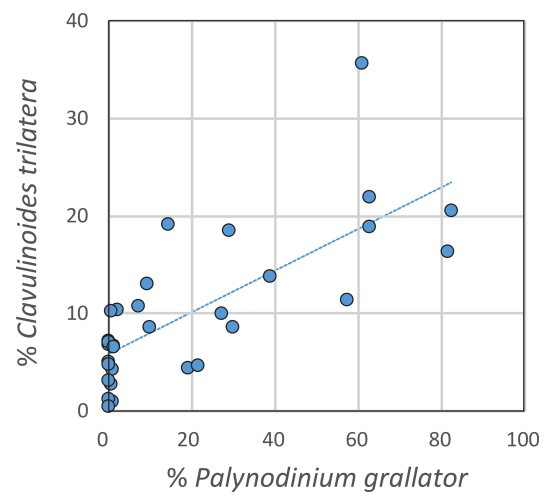

Figure 7. Correlation between the relative abundances of $\mathrm{Pa}$ lynodinium grallator and Clavulinoides trilatera $\left(R^{2}=0.55 ; p\right.$ value $<0.01)$.

\section{Conclusions}

Our records show that the LMWE resulted in a period of intensive enhanced dinoflagellate-cyst production at midlatitude shelves along the North Atlantic. This enhanced dinoflagellate-cyst production persisted during the LMWE and resulted from seasonally recurring ecosystem stress. The warm, seasonally stratified shallow seas resulted in repeatedly favorable conditions for particular cyst-producing dinoflagellate taxa, supporting the massive abundance of $P$. grallator in our records. Our study therefore indicates that shallow marine phytoplankton communities experienced major community level shifts in response to latest Cretaceous global warming. While we cannot positively confirm that the recorded amplified dinoflagellate-cyst production is linked to actual dinoflagellate blooms, we hypothesize that throughout the LMWE the conditions were likely more frequently favorable for dinoflagellate blooms, potentially resulting in recurrent blooms. Dinoflagellate-cyst production was more intense in the open marine seasonally stratified sites, compared to nearshore sites, highlighting a possible heterogeneous response to climate change across late Maastrichtian shelves. The benthic foraminiferal record of Bass River indicates that the LMWE, and related dinoflagellate-cyst production, resulted in a stressed benthic ecosystem with a reduced benthic foraminiferal diversity. While the dinocyst assemblage returned to a stable, normal marine community in the last tens of thousands of years of the Maastrichtian, benthic foraminiferal diversity remained slightly suppressed. This increased ecosystem stress during the latest Maastrichtian potentially primed global ecosystems for the subsequent mass extinction following the K-Pg boundary Chicxulub impact.

Data availability. All data related to this publication are available in the Supplement and at the PANGAEA database (https://doi. pangaea.de/10.1594/PANGAEA.907070, Vellekoop et al., 2019). 
Supplement. The supplement related to this article is available online at: https://doi.org/10.5194/bg-16-4201-2019-supplement.

Author contributions. JV conceived the study; JV and LW generated the data. All authors contributed to the writing of the manuscript.

Competing interests. The authors declare that they have no conflict of interest.

Acknowledgements. This research has been supported by the Fonds Wetenschappelijk Onsderzoek (FWO).

Financial support. This work was funded by Fonds Wetenschappelijk Onderzoek (FWO; grant nos. G.0B85.13 (to Robert P. Speijer) and $12 \mathrm{Z} 6618 \mathrm{~N}$ (to Johan Vellekoop)). Appy Sluijs thanks the European Research Council for the Consolidator Grant. This publication was made possible through funding support of the KU Leuven Fund for Fair Open Access.

Review statement. This paper was edited by Markus Kienast and reviewed by Nicolas Thibault and Kasia K. Sliwinska.

\section{References}

Almeda, R., Cosgrove, S., and Buskey, E. J.: Oil spills and dispersants can cause the initiation of potentially harmful dinoflagellate blooms ("red tides"), Environ. Sci. Technol., 52, 5718-5724, https://doi.org/10.1021/acs.est.8b00335, 2018.

Beaugrand, G., Conversi, A., Atkinson, A., Cloern, J., Chiba, S., Kirby, R. R., Greene, C. H., Goberville, E., Otto, S. A., Reid, P. C., Stemmann, L., and Edwards, M.: Prediction of unprecedented biological shifts in the global ocean, Nat. Clim. Change, 9, 237243, https://doi.org/10.1038/s41558-019-0420-1, 2019.

Behrenfeld, M. J., O’Malley, R. T., Siegel, D. A., McClain, C. R., Sarmiento, J. L., Feldman, G. C., Milligan, A. J., Falkowski, P. G., Letelier, R. M., and Boss, E. S.: Climate-driven trends in contemporary ocean productivity, Nature, 444, 752-755, https://doi.org/10.1038/nature05317, 2006.

Bohaty, S. M. and Zachos, J. C.: Significant Southern Ocean warming event in the late middle Eocene, Geology, 11, 1017-1020, 2003.

Boyd, P. W. and Doney, S. C.: Modelling regional responses by marine pelagic ecosystems to global climate change, Geophys. Res. Lett., 29, 1806, https://doi.org/10.1029/2001gl014130, 2002.

Brinkhuis, H.: Late Eocene to Early Oligocene dinoflagellate cysts from the Priabonian type-area (Northeast Italy): biostratigraphy and paleoenvironmental interpretation, Palaeogeogr. Palaeocl., 107, 121-163, https://doi.org/10.1016/0031-0182(94)90168-6, 1994.

Brinkhuis, H., Bujak, J. P., Smit, J., Versteegh, G. J. M., and Visscher, H.: Dinoflagellate-based sea surface temperature re- constructions across the Cretaceous-Tertiary boundary, Palaeogeogr. Palaeocl., 141, 67-83, https://doi.org/10.1016/S00310182(98)00004-2, 1998.

Cramwinckel, M. J., Ploeg, R. Van Der, Bijl, P. K., Peterse, F., Bohaty, S. M., Röhl, U., Schouten, S., Middelburg, J. J., and Sluijs, A.: Harmful algae and export production collapse in the equatorial Atlantic during the zenith of Middle Eocene Climatic Optimum warmth, Geology, 47, 1-4, https://doi.org/10.1130/G45614.1, 2019.

Doney, S. C.: Plankton in a warmer world, Nature, 444, 695-696, 2006.

Eppley, R. W.: Temperature and phytoplankton growth in the sea, Fish. B., 70, 1063-1085, 1972.

Esmeray-Senlet, S., Wright, J. D., Olsson, R. K., Miller, K. G., Browning, J. V., and Quan, T. M.: Evidence for reduced export productivity following the Cretaceous/Paleogene mass extinction, Paleoceanography, 30, 1-21, https://doi.org/10.1002/2014PA002724, 2015.

Falkowski, P. G., Katz, M. E., Knoll, A. H., Quigg, A., Raven, J. A., Schofield, O., and Taylor, F. J. R.: The evolution of modern eukaryotic phytoplankton, Science, 305, 354-360, https://doi.org/10.1126/science.1095964, 2004.

Frieling, J. and Sluijs, A.: Towards quantitative environmental reconstructions from ancient non-analogue microfossil assemblages: Ecological preferences of PaleoceneEocene dinoflagellates, Earth-Sci. Rev., 185, 956-973, https://doi.org/10.1016/j.earscirev.2018.08.014, 2018.

Frieling, J., Reichart, G.-J., Middelburg, J. J., Röhl, U., Westerhold, T., Bohaty, S. M., and Sluijs, A.: Tropical Atlantic climate and ecosystem regime shifts during the Paleocene-Eocene Thermal Maximum, Clim. Past, 14, 39-55, https://doi.org/10.5194/cp-1439-2018, 2018.

Hallegraeff, G. M.: A review of harmful algal blooms and their apparent global increase, Phycologia, 32, 79-99, https://doi.org/10.2216/i0031-8884-32-2-79.1, 1993.

Hallegraeff, G. M.: Ocean climate change, phytoplankton community responses, and harmful algal blooms: A formidable predictive challenge, J. Phycol., 46, 220-235, https://doi.org/10.1111/j.1529-8817.2010.00815.x, 2010.

Hay, W. W.: Can humans force a return to a "Cretaceous" climate?, Sediment. Geol., 235, 5-16, https://doi.org/10.1016/j.sedgeo.2010.04.015, 2011.

Henehan, M. J., Hull, P. M., Penman, D. E., Rae, J. W. B., and Schmidt, D. N.: Biogeochemical significance of pelagic ecosystem function: an end-Cretaceous case study, Philos. T. R. Soc. B, 371, 20150510, https://doi.org/10.1098/rstb.2015.0510, 2016.

Jorissen, F. J., Fontanier, C., and Thomas, E.: Paleoceanographical proxies based on deep-sea benthic foraminiferal assemblage characteristics, in: Proxies in Late Cenozoic Paleoceanography: Pt. 2, edited by: Hillaire-Marcel, C. and de Vernal, A., 263-326, Elsevier, Middletown, Connecticut, USA, 2007.

Kitazato, H., Shirayama, Y., Nakatsuka, T., Fujiwara, S., Shimanaga, M., Kato, Y., Okada, Y., Kanda, J., Yamaoka, A., Masuzawa, T., and Suzuki, K.: Seasonal phytodetritus deposition and responses of bathyal benthic foraminiferal populations in Sagami Bay, Japan: Preliminary results from "Project Sagami 1996-1999", Mar. Micropaleontol., 40, 135149, https://doi.org/10.1016/S0377-8398(00)00036-0, 2000. 
Lee, J. J.: Tracer expiriments in feeding littoral forminifera, J. Protozool., 13, 659-670, 1966.

Machalski, M., Vellekoop, J., Dubicka, Z., Peryt, D., and Harasimiuk, M.: Late Maastrichtian cephalopods, dinoflagellate cysts and foraminifera from the Cretaceous-Paleogene succession at Lechówka, southeast Poland: Stratigraphic and environmental implications, Cretaceous Res., 57, 208-227, https://doi.org/10.1016/j.cretres.2015.08.012, 2016.

Miller, K. G., Sugarman, P. J., Browning, J. V, Olsson, R. K., Pekar, S. F., Reilly, T. J., Cramer, B. S., Aubry, M.-P., Lawrence, R. P., Curran, J., Stewart, M., Metzger, J. M., Uptegrove, J., Bukry, D., Burckle, L. H., Wright, J. D., Feigenson, M. D., Brenner, G. J., Dalton, R. F., and Browning, L.: Bass river site, Proc. Ocean Drill. Program, Initial Reports, 174AX, 5-43, https://doi.org/10.2973/odp.proc.ir.174AX.1998, 1998.

Miller, K. G., Sherrell, R. M., Browning, J. V, Field, M. P., Gallagher, W., Olsson, R. K., Sugarman, P. J., Tuorto, S., and Wahyudi, H.: Relationship between mass extinction and iridium across the Cretaceous-Paleogene boundary in New Jersey, Geology, 38, 867-870, https://doi.org/10.1130/G31135.1, 2010.

Moore, S. K., Trainer, V. L., Mantua, N. J., Parker, M. S., Laws, E. A., Backer, L. C., and Fleming, L. E.: Impacts of climate variability and future climate change on harmful algal blooms and human health, Environ. Heal., 7, S4, https://doi.org/10.1186/1476069X-7-S2-S4, 2008.

Nøhr-Hansen, H., Williams, G. L., and Fensome, R. A.: Biostratigraphic correlation of the western and eastern margins of the Labrador - Baffin Seaway and implications for the regional geology, Geol. Surv. Den. Greenl., 37, 1-77, 2016.

Olsson, R. K., Miller, K. G., Browning, J. V., Wright, J. D., and Cramer, B. S.: Sequence stratigraphy and sea-level change across the Cretaceous-Tertiary boundary on the New Jersey passive margin, in: Catastrophic Events and Mass Extinctions: Impacts and Beyond, Vol. 356, edited by: Koeberl, C. and Macleod, K. G., 97-108, Geological Society of America Special Paper, Boulder, Colorado, 2002.

Pachauri, R. K., Allen, M. R., Barros, V. R., Broome, J., Cramer, W., Christ, R., Church, J. A., Clarke, L., Dahe, Q., Dasgupta, P., Dubash, N. K., Edenhofer, O., Elgizouli, I., Field, C. B., Forster, P., Friedlingstein, P., Fuglestvedt, J., Gomez-Echeverri, L., Hallegatte, S., Hegerl, G., Howden, M., Jiang, K., Jimenez Cisneros, B., Kattsov, V., Lee, H., Mach, K. J., Marotzke, J., Mastrandrea, M. D., Meyer, L., Minx, J., Mulugetta, Y., O’Brien, K., Oppenheimer, M., Pereira, J. J., Pichs-Madruga, R., Plattner, G.-K., Pörtner, H.-O., Power, S. B., Preston, B., Ravindranath, N. H., Reisinger, A., Riahi, K., Rusticucci, M., Scholes, R., Seyboth, K., Sokona, Y., Stavins, R., Stocker, T. F., Tschakert, P., van Vuuren, D., and van Ypersele, J.-P.: Climate Change 2014: Synthesis Report. Contribution of Working Groups I, II and III to the fifth assessment report of the Intergovernmental Panel on Climate Change, edited by: Pachauri, R. K. and Meyer, L., IPCC, Geneva, Switzerland, 2014.

Petersen, S. V, Dutton, A., and Lohmann, K. C.: End-Cretaceous extinction in Antarctica linked to both Deccan volcanism and meteorite impact via climate change, Nat. Commun., 7, 12079, https://doi.org/10.1038/ncomms12079, 2016.

Pitcher, G. C., Figueiras, F. G., Hickey, B. M., and Moita, M. T.: The physical oceanography of upwelling systems and the de- velopment of harmful algal blooms, Prog. Oceanogr., 85, 5-32, https://doi.org/10.1016/j.pocean.2010.02.002, 2010.

Ravizza, G. and Peucker-Ehrenbrink, B.: Chemostratigraphic evidence of Deccan volcanism from the marine osmium isotope record, Science, 302, 1392-1395, https://doi.org/10.1126/science.1089209, 2003.

Schiøler, P. and Wilson, G. J.: Maastrichtian dinoflagellate zonation in the Dan Field, Danish North Sea, Rev. Palaeobot. Palyno., 78, 312-351, https://doi.org/10.1016/0034-6667(93)90070-B, 1993.

Schiøler, P., Brinkhuis, H., Roncaglia, L., and Wilson, G. J.: Dinoflagellate biostratigraphy and sequence stratigraphy of the type Maastrichtian (Upper Cretaceous), ENCI Quarry, The Netherlands, Mar. Micropaleontol., 31, 65-95, https://doi.org/10.1016/S0377-8398(96)00058-8, 1997.

Schoene, B., Samperton, K. M., Eddy, M. P., Keller, G., Adatte, T., Bowring, S. A., Khadri, S. F. R., and Gertsch, B.: $\mathrm{U}-\mathrm{Pb}$ geochronology of the Deccan Traps and relation to the end-Cretaceous mass extinction, Science, 347, 182-184, https://doi.org/10.1126/science.aaa0118, 2015.

Schouten, S., Hopmans, E. C., Schefuß, E., and Sinninghe Damsté, J. S.: Distributional variations in marine crenarchaeotal membrane lipids: A new tool for reconstructing ancient sea water temperatures?, Earth Planet. Sc. Lett., 204, 265-274, https://doi.org/10.1016/S0012-821X(02)00979-2, 2002.

Schulte, P., Alegret, L., Arenillas, I., Arz, J. A., Barton, P. J., Bown, P. R., Bralower, T. J., Christeson, G. L., Claeys, P., Cockell, C. S., Collins, G. S., Deutsch, A., Goldin, T. J., Goto, K., Grajales-Nishimura, J. M., Grieve, R. A. F., Gulick, S. P. S., Johnson, K. R., Kiessling, W., Koeberl, C., Kring, D. A., MacLeod, K. G., Matsui, T., Melosh, J., Montanari, A., Morgan, J. V, Neal, C. R., Nichols, D. J., Norris, R. D., Pierazzo, E., Ravizza, G., Rebolledo-vieyra, M., Reimold, W. U., Robin, E., Salge, T., Speijer, R. P., Sweet, A. R., UrrutiaFucugauchi, J., Vajda, V., Whalen, M. T., and Willumsen, P. S.: The Chicxulub asteroid impact and mass extinction at the Cretaceous-Paleogene Boundary, Science, 327, 1214-1218, https://doi.org/10.1126/science.1177265, 2010.

Sheldon, E., Ineson, J., and Bown, P.: Late Maastrichtian warming in the Boreal Realm: Calcareous nannofossil evidence from Denmark, Palaeogeogr. Palaeocl., 295, 55-75, https://doi.org/10.1016/j.palaeo.2010.05.016, 2010.

Sluijs, A. and Brinkhuis, H.: A dynamic climate and ecosystem state during the Paleocene-Eocene Thermal Maximum: inferences from dinoflagellate cyst assemblages on the New Jersey Shelf, Biogeosciences, 6, 1755-1781, https://doi.org/10.5194/bg-61755-2009, 2009.

Sluijs, A., Pross, J., and Brinkhuis, H.: From greenhouse to icehouse; organic-walled dinoflagellate cysts as paleoenvironmental indicators in the Paleogene, Earth-Sci. Rev., 68, 281-315, https://doi.org/10.1016/j.earscirev.2004.06.001, 2005.

Thibault, N. and Gardin, S.: Maastrichtian calcareous nannofossil biostratigraphy and paleoecology in the Equatorial Atlantic (Demerara Rise, ODP Leg 207 Hole 1258A), Rev. Micropaléontologie, 49, 199-214, https://doi.org/10.1016/j.revmic.2006.08.002, 2006.

Thibault, N. and Husson, D.: Climatic fluctuations and sea-surface water circulation patterns at the end of the Cretaceous era: Calcareous nannofossil evidence, Palaeogeogr. Palaeocl., 441, 152164, https://doi.org/10.1016/j.palaeo.2015.07.049, 2016. 
Vellekoop, J., Smit, J., van de Schootbrugge, B., Weijers, J. W. H., Galeotti, S., Sinninghe Damsté, J. S., and Brinkhuis, H.: Palynological evidence for prolonged cooling along the Tunisian continental shelf following the $\mathrm{K}$ Pg boundary impact, Palaeogeogr. Palaeocl., 426, 216-228, https://doi.org/10.1016/j.palaeo.2015.03.021, 2015.

Vellekoop, J., Esmeray-Senlet, S., Miller, K. G., Browning, J. V., Sluijs, A., van de Schootbrugge, B., Sinninghe Damsté, J. S., and Brinkhuis, H.: Evidence for Cretaceous-Paleogene boundary bolide "impact winter" conditions from New Jersey, USA, Geology, 44, 619-622, https://doi.org/10.1130/G37961.1, 2016.

Vellekoop, J., Holwerda, F., Prámparo, M. B., Willmott, V., Schouten, S., Cúneo, N. R., Scasso, R. A., and Brinkhuis, H.: Climate and sea-level changes across a shallow marine CretaceousPalaeogene boundary succession in Patagonia, Argentina, Palaeontology, 60, 519-534, https://doi.org/10.1111/pala.12297, 2017.

Vellekoop, J., Woelders, L., van Helmond, N. A. G. M., Galeotti, S., Smit, J., Slomp, C. P., Brinkhuis, H., Claeys, P., and Speijer, R. P.: Shelf hypoxia in response to global warming after the Cretaceous-Paleogene boundary impact, Geology, 46, 683-686, https://doi.org/10.1130/G45000.1, 2018.

Vellekoop, J., Woelders, L., Sluijs, A., Miller, K. G., and Speijer, R. P.: Latest Maastrichtian dinocyst and benthic foraminiferal records of Bass River, Meirs Farm and Search Farm sediment cores, New Jersey, USA, PANGAEA, https://doi.org/10.1594/PANGAEA.907070, 2019.
Waggett, R. J., Hardison, D. R., and Tester, P. A.: Toxicity and nutritional inadequacy of Karenia brevis: Synergistic mechanisms disrupt top-down grazer control, Mar. Ecol.-Prog. Ser., 444, 1530, https://doi.org/10.3354/meps09401, 2012.

Williams, G. L., Brinkhuis, H., Pearce, M. A., Fensome, R. A., and Weegink, J. W.: Southern Ocean and global dinoflagellate cyst events compared: index events for the Late Cretaceous-Neogene, in: Proceedings of the Ocean Drilling Program, Scientific Results, Vol. 189, edited by: Exon, N. F., Kennett, J. P., and Malone, M. J., 1-98, Ocean Drilling Program, College Station, Texas, USA, 2004.

Woelders, L., Vellekoop, J., Kroon, D., Smit, J., Casadio, S., Prámparo, M. B., Dinarès-Turell, J., Peterse, F., Sluijs, A., and Speijer, R. P.: Latest Cretaceou climatic and environmental change in the South Atlantic region, Paleoceanography, 32, 1-18, https://doi.org/10.1002/2016PA003007, 2017.

Woelders, L., Vellekoop, J., Weltje, G. J., de Nooijer, L., Reichart, G.-J., Peterse, F., Claeys, P., and Speijer, R. P.: Robust multiproxy data integration, using late Cretaceous paleotemperature records as a case study, Earth Planet. Sc. Lett., 500, 215-224, https://doi.org/10.1016/j.epsl.2018.08.010, 2018. 